\title{
Pharmacokinetic Drugs Interaction and Management in Margono Soekarjo Hospital in Stroke Patients
}

\author{
$1^{\text {st }}$ Desy Nawangsari \\ Departement of Pharmacy \\ Harapan Bangsa University \\ Banyumas, Indonesia \\ email : desynawangsari@uhb.ac.id
}

\author{
$2^{\text {nd }}$ Ikhwan Yuda Kusuma \\ Departement of Pharmacy \\ Harapan Bangsa University \\ Banyumas, Indonesia \\ email : ikhwanyudakusuma@uhb.ac.id
}

\begin{abstract}
Stroke is a functional brain disorder in the form of nerve paralysis (neurologic deficit) due to blocked blood flow to the brain. Therapy in stroke patients usually gets more than two kinds of drugs so that drug interactions often occur. One mechanism of drug interaction is pharmacokinetics. Pharmacokinetic interactions occur when a drug affects the absorption, distribution, metabolism and excretion of other drugs thereby increasing or decreasing the amount of drug available to produce its pharmacological effects. This study aims to determine the potential pharmacokinetic drug interaction and management in stroke patients in Margono Soekarjo Hospital. The method of this study was descriptive study with cross sectional approach (1-30 June 2019). Data were analyzed descriptively using Stockley's Drug Interaction, Drug Interaction Facts and www.drugs.com database. Medscape Drug Interactions Checker. The results showed that from 27 stroke patients there were $38.60 \%$ pharmacokinetic interaction events. The most common pharmacokinetic interaction was interaction between mecobalamin and ranitidine.
\end{abstract}

Keywords: drug interaction, hospital, pharmacokinetic, stroke

\section{INTRODUCTION}

Stroke is a functional brain disorder in the form of nerve paralysis (neurologic deficit) due to obstruction of blood flow to the brain, including signs or symptoms of loss of nervous system function. Stroke can cause symptoms and cause and effect. Symptoms caused by a stroke last more than 24 hours and can cause death, in addition to causing death, a stroke also has an impact on life [1].

Every year, there are 15 million people around the world who suffer from strokes. In Southeast Asia there are 4.4 million people suffering from strokes, while in Indonesia, it is estimated that around $800-1,000$ cases of stroke occur each year. Deaths from strokes by $51 \%$ worldwide are caused by high blood pressure. In addition, about $16 \%$ of deaths in stroke are caused by high blood glucose levels. In 2020 an estimated 7.6 million people may die from stroke[1]

Factors that can cause a stroke are grouped into risk factors that cannot be changed and risk factors that can be changed. Risk factors that cannot be changed include an increase in age and sex. Risk factors that can be changed include hypertension, diabetes mellitus and dyslipidemia. Various types of risk factors for stroke must be resolved to improve quality and maintain patient's life. However, the number of drugs used for therapy may trigger things that cannot be avoided such as the possibility of treatment results that are not as expected. The use of many drugs (polypharmacy) is very risky to cause interactions between one drug with another drug, although all drug administration has a clinical indication[2].

The mechanism of drug interactions can be divided into interactions that involve the pharmacokinetic aspects of the drug, and interactions that affect the pharmacodynamics response of the drug[3].

Pharmacokinetic interactions occur when a drug affects the absorption, distribution, metabolism and excretion of other drugs, thereby increasing or decreasing the amount of drug available to provide pharmacological effects[4]. This can cause toxicity or reduced efficacy of stroke drugs with non-stroke drugs. Interactions that occur are the use of mecobalamin and ranitidine together which causes potential pharmacokinetic interactions in the absorption phase, when ranitidine interferes with the absorption of vitamin B12 (mecobalamin) [5].

Considering that the stroke is a health problem with increasing prevalence, morbidity and mortality, as well as a very large risk of drug interactions, it is necessary to identify potential pharmacokinetic interactions of drugs in stroke patients at Prof. Dr. Margono Soekarjo Hospital Purwokerto.

\section{METHODS}

The design of this study is a descriptive study with cross sectional approach. The data was obtained from the results of retrospective data collection from the medical records of Margono Soekarjo Hospital in Purwokerto. Medical records were taken from June 1 to 30, 2019 using the total sampling method. The inclusion criteria of this study were stroke patients in 1-30 June 2019 and medical record sheets containing two or more (prescription) drug. Furthermore, medical records were identified through Stockley's Drug Interaction literature, Drug Interaction Facts, www.drug.com data base and Medscape Drug Interactions Checker. The data obtained are categorized based on interactions with the pharmacokinetic mechanisms that occur. 


\section{RESULTS AND DISCUSSION}

This research was conducted by retrospective method, by looking directly at the observation sheet of stroke patients in the inpatient installation of Margono Soekarjo Regional Hospital on 1-30 June 2019 with 27 patients. During the study period, there were $21(38.6 \%)$ interactions with pharmacokinetic mechanisms from 27 medical records at Margono Soekarjo Hospital Purwokerto. The results of the study were divided into 2 sections including patient characteristics data, which consisted of gender, age, and patient's treatment data received when receiving treatment. The characteristics of the research subjects are as follows:

\section{A. Patient Characteristics Based on Gender}

Gender is one factor that cannot be changed. The grouping of stroke patients by gender can be seen in Table 1.

TABLE 1. CHARACTERISTICS OF STROKE PATIENTS BY GENDER

\begin{tabular}{|c|c|c|c|}
\hline \multicolumn{2}{|c|}{$\begin{array}{c}\text { Patient } \\
\text { Characteristic }\end{array}$} & $\begin{array}{c}\text { Number of } \\
\text { Patients }\end{array}$ & $\begin{array}{c}\text { Percentage } \\
(\%)\end{array}$ \\
\hline \multirow{2}{*}{ Gender } & Male & 17 & 62,96 \\
\cline { 2 - 4 } & Female & 10 & 37,04 \\
\hline \multicolumn{2}{|c|}{ Total } & 27 & 100 \\
\hline
\end{tabular}

In Table 1 it can be seen that the characteristics of patients by gender, the prevalence of stroke in male is more $(62.96 \%)$ compared to female $(37.04 \%)$. Certain stroke risk factors are known to affect each sex. This shows that stroke affects more in male than female. Smoking habits and a history of alcohol consumption were found to be more dominant in men [6].

\section{B. Patient characteristics Based on age}

Patient characterization was also performed to see patient criteria based on age on the patient's medical record.

TABLE 2. CHARACTERISTICS OF STROKE PATIENTS BY AGE
\begin{tabular}{|c|c|c|c|}
\hline \multirow{2}{*}{$\begin{array}{c}\text { Patient Characteristic } \\
\text { (year) }\end{array}$} & $\begin{array}{c}\text { Number of } \\
\text { Patients }\end{array}$ & $\begin{array}{c}\text { Percentage } \\
\mathbf{( \% )}\end{array}$ \\
\hline \multirow{3}{*}{ Age } & $41-50$ & 3 & 11,11 \\
\cline { 2 - 4 } & $51-60$ & 6 & 22,22 \\
\cline { 2 - 4 } & $61-70$ & 18 & 66,67 \\
\hline Total & & 27 & 100 \\
\hline
\end{tabular}

Based on the data in table 2, the highest frequency of stroke patients aged 61-70 years was $66.67 \%$ of patients, followed by ages $51-60$ years $(22.22 \%)$, then aged $41-50$ years at $11.11 \%$. The increase in the frequency of strokes with increasing age is related to the aging process, where all organs of the body experience deterioration of function including the blood vessels of the brain. The blood vessels become inelastic, especially the endothelial part that experiences thickening in the intima, resulting in narrowed lumen of the blood vessels and an impact on decreasing cerebral blood flow [7]

\section{Occurrences of Drug Interactions with Pharmacokinetic Mechanisms}

Pharmacokinetic interactions due to polypharmacy in stroke patients can be seen in Table 3 .

TABLE 3. POTENTIAL DRUG INTERACTIONS IN STROKE PATIENTS BASED ON THE NUMBER OF MEDICAL RECORDS

\begin{tabular}{|l|c|c|}
\hline Interaction Events & $\begin{array}{c}\text { Number of Medical } \\
\text { Records }\end{array}$ & $\begin{array}{c}\text { Percentage } \\
(\boldsymbol{\%})\end{array}$ \\
\hline Interaction Occurs & 21 & 77,78 \\
\hline No Interaction Occurs & 6 & 22,22 \\
\hline Total & 27 & 100 \\
\hline
\end{tabular}

Based on the data in table 3 , in the therapy received by 27 stroke patients, the percentage of the number of medical records with interacting drugs was 21 medical records $(77.78 \%)$ and 6 medical records among them $(22.22 \%)$ did not experience drug interactions. So it can be seen that the number of medical records with drugs that interact more than the number of medical records that do not experience drug interactions. The more drugs the patient uses, the higher the probability of drug interactions.

Drug interactions on medical record data taken were identified using Stockleys, Tatro, and drug interactions.com. Drug interactions observed in this study are potential drug interactions which are interactions between drugs that may occur in patients after taking them. Identified drug interactions were 34 combinations. Potential drug interactions are divided into two components based on the mechanism of drug interactions and the severity of interactions with pharmacokinetic mechanisms. The results in this study can be said of the latest data for potential drug interactions in the inpatient installation of Margono Soekarjo Regional Hospital.

\section{Pharmacokinetic Interactions Based on Severity}

TABLE 4. PERCENTAGE OF PHARMACOKINETIC INTERACTIONS OF DRUGS IN STROKE PATIENTS BASED ON SEVERITY

\begin{tabular}{|c|c|c|}
\hline Severity & $\begin{array}{c}\text { Number of } \\
\text { Interaction Types }\end{array}$ & Percentage (\%) \\
\hline Major & 0 & 0 \\
\hline Moderate & 7 & 33,33 \\
\hline Minor & 14 & 66,67 \\
\hline Total & 21 & 100 \\
\hline
\end{tabular}

In table 4 , the percentage of pharmacokinetic interaction groups based on the severity that has been analyzed, in the major group there was no interaction, in the minor group as many as 14 drug interaction events $(66.67 \%)$ and moderate groups as many as 7 drug interaction events $(33.33 \%)$. In this study it can be seen that most drug interactions occur in the minor category. Drug interactions with minor severity usually have mild effects, but due to the large number of interactions in this group, the use of a combination of drugs needs to be considered again, because the consequences may be disturbing although they do not significantly affect the outcome of therapy[4]. 
It can be concluded that polypharmacy increases the potential for drug interactions, therefore the use of additional therapy can be considered based on studies related to patient's medical problems that refer to the rationality of treatment.

\section{E. Interactions Based on Phase Distribution in Pharmacokinetic Interactions}

TABLE 5. PERCENTAGE OF PHASE DISTRIBUTIONS IN PHARMACOKINETIC INTERACTIONS

\begin{tabular}{|c|c|c|c|}
\hline No & $\begin{array}{c}\text { Pharmacokinetic } \\
\text { Interaction Phase }\end{array}$ & $\begin{array}{c}\text { Number of } \\
\text { events }\end{array}$ & $\begin{array}{c}\text { Percentage } \\
(\boldsymbol{\%})\end{array}$ \\
\hline 1 & Absorption & 14 & 66,67 \\
\hline
\end{tabular}

\begin{tabular}{|c|c|c|c|}
\hline 2 & Distribution & 2 & 9,52 \\
\hline 3 & Metabolism & 4 & 19.04 \\
\hline 4 & Excretion & 1 & 4,77 \\
\hline \multicolumn{2}{|c|}{ Total } & 21 & 100 \\
\hline
\end{tabular}

Pharmacokinetic interactions in the treatment of stroke consist of 4 phases, including the absorption phase of 14 events (66.67\%), the distribution phase of 2 events $(9.52 \%)$, the metabolic phase of 4 events $(19.04 \%)$ and the excretion phase as many as 1 incident $(4.77 \%)$. This shows that the most drug interactions that occur are in the absorption phase.

\section{F. Identification of Interactions Based on Pharmacokinetic Interaction Mechanisms}

TABLE 6. IDENTIFICATION OF PHARMACOKINETIC DRUG INTERACTIONS

\begin{tabular}{|c|c|c|c|c|c|}
\hline Drugs A & Drugs B & Phase & Interaction Effect & $\begin{array}{l}\text { Number of } \\
\text { Interaction }\end{array}$ & $\begin{array}{l}\text { Precentage } \\
(\%)\end{array}$ \\
\hline Aspirin & Omeprazole & Absorption & Omeprazole increases gastric $\mathrm{pH}$ (4) (5). & 2 & 9,53 \\
\hline Ciprofloxacin & Furosemide & Distribution & $\begin{array}{l}\text { Furosemide increases plasma concentrations of ciprofloxacin } \\
\text { (5). }\end{array}$ & 1 & 4,76 \\
\hline Furosemide & Ketorolak & Excretion & Ketorolac causes sodium and water retention (5). & 1 & 4,76 \\
\hline Ketorolac & Ranitidin & Distribution & $\begin{array}{l}\text { Ranitidine changes the disposition of nonsteroidal anti- } \\
\text { inflammatory drugs (NSAIDs), resulting in an increase or } \\
\text { decrease in plasma concentration(5). }\end{array}$ & 1 & 4,76 \\
\hline Mecobalamin & Ranitidine & Absorption & $\begin{array}{l}\text { Ranitidine interferes with the absorption of vitamin B12 } \\
\text { (mecobalamin) (5). }\end{array}$ & 6 & 28,58 \\
\hline Mecobalamin & Omeprazole & Absorption & $\begin{array}{l}\text { Omeprazole interferes with the absorption of vitamin B12 } \\
\text { (mecobalamin) (5). }\end{array}$ & 4 & 19,05 \\
\hline Omeprazole & Ferro sulfat & Absorption & $\begin{array}{l}\text { Omeprazole interferes with gastrointestinal absorption from } \\
\text { non-heme iron (5). }\end{array}$ & 2 & 9,52 \\
\hline Phenytoin & Amitriptyline & Metabolism & $\begin{array}{l}\text { Tricyclic antidepressants can increase serum phenytoin levels } \\
\text { (5). }\end{array}$ & 1 & 4,76 \\
\hline Phenytoin & Diazepam & Metabolism & $\begin{array}{l}\text { Diazepam changes the serum concentration of phenytoin, both } \\
\text { increasing and decreasing (5). }\end{array}$ & 1 & 4,76 \\
\hline Phenytoin & Alprazolam & Metabolism & $\begin{array}{l}\text { Alprazolam changes the serum concentration of phenytoin, } \\
\text { which can be an increase or decrease in concentration(5). }\end{array}$ & 1 & 4,76 \\
\hline Phenytoin & Amlodipine & Metabolism & Amlodipine can increase plasma phenytoin levels(5).. & 1 & 4,76 \\
\hline \multicolumn{4}{|r|}{ Total } & 21 & 100 \\
\hline
\end{tabular}

From table 6 it can be seen that the largest percentage of pharmacokinetic interactions in the absorption phase is the interaction between mecobalamin and ranitidine as many as 6 events $(28.58 \%)$ followed by mecobalamin and omeprazole interactions by 4 (19.05\%). Mechanisms that occur between mecobalamin and ranitidine used simultaneously, Ranitidin interferes with the absorption of vitamin B12 (Mecobalamin) (Drugs.com, 2019) as well as the mechanism that occurs between mecobalamin and omeprazole, which Omeprazole interferes with the absorption of vitamin B12 (mecobalamin)[5].

Reduction or suppression of gastric acid secretion by $\mathrm{H} 2$ receptor antagonists and proton pump inhibitors can interfere with the absorption of mecobalamin in the digestive tract, a process that depends on the presence of stomach acid and pepsin. Clinical studies have shown that a diet of mecobalamin (ie protein bound) malabsorption can occur during treatment with this agent, especially proton pump inhibitors, although the possibility of developing clinically significant deficiencies over time is unknown. There has been one case of vitamin B12 deficiency (mecobalamin) reported with megaloblastic anemia in patients who received omeprazole for at least $40 \mathrm{mg} /$ day for 4 years. Also uncertain is whether the reduction or suppression of acid can affect the absorption of vitamin B12 (mecobalamin) which is digested in the form of oral supplements such as cyanocobalamin[8].

Management to resolve this interaction is to provide a route of non-oral administration such as (parenteral, intranasal, sublingual) which is generally preferred in the treatment of anemia related to B12 deficiency (mecobalamin)[5].

\section{CONCLUSION}

The results showed that of 27 stroke patients there were $21(38.60 \%)$ patients who experienced pharmacokinetic interaction events. The most common pharmacokinetic interaction is mecobalamin with ranitidine which is used together with the mechanism of Ranitidin to interfere with the absorption of vitamin B12 (Mecobalamin). 
Company; 2009.

\section{ACKNOWLEDGMENT}

This study was conducted based on the funding given by Harapan Bangsa University, Indonesia based on the annual research grant year 2018/2019.

\section{REFERENCES}

1. Junaidi I. Stroke Waspadai Ancamannya. Yogyakarta: Andi Offset; 2011.

2. Terrie Y. Understanding and Managing Polypharmacy in the Elderly. 2004;

3. Baxter K. Stockley' s Drug Interactions Eighth Edition. 2008;

4. Tatro DS. Drug Interaction Facts. A Wolters Kluwer
5. Drugs.com. drug interactions checker. www.drugs.com. 2019.

6. Watila MM, Nyandaiti YW, Bwala SA, Ibrahim A. Gender variation in risk factors and clinical presentation of acute stroke , Northeastern Nigeria. 2011;3(March):38-43.

7. Kristiyawati SPDITSH. Faktor Risiko yang Berhubungan dengan Kejadian Stroke di Rumah Sakit Panti Wilasa Citarum Semarang. 2009.Notoatmodjo S. Metodologi Penelitian Kesehatan. 2010. 